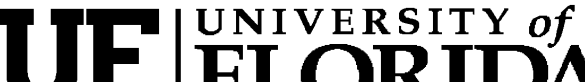 FLORIDA \\ IFAS Extension
}

FCS3268

\section{Energy Efficient Homes: Incentive Programs for Energy Efficiency ${ }^{1}$}

Nicholas W. Taylor, M. Jennison Kipp, and Kathleen C. Ruppert ${ }^{2}$

\section{Quick Facts}

- Most utility providers offer home energy audits, at little or no cost, to help customers identify particular areas where energy efficiency improvements can be made.

- In most Florida homes, the greatest return on energy efficiency improvements are in updating a home's attic insulation, windows, and/or air conditioning system. Incentive programs often target these very types of improvements.

\section{Terms to Help You Get Started}

- Incentive Encouragement, often financial, for customers to make use of a particular product, type of product, or service.

- Demand-Side Management The use of incentive programs by a utility provider to increase the energy efficiency and lower the operating costs of customers' homes.
- Energy Audit An inspection, survey, and analysis of an occupied building to prioritize its energy uses with an eye towards reducing energy consumption while maintaining or improving human comfort, health, and safety. Feedback typically emphasizes the most cost-effective opportunities for energy savings.

- Utility Rebate Money given by the utility provider to customers after they have purchased and installed a new product or service. The intent is to encourage energy efficiency improvements by offsetting the final cost of the product or service.

- Energy Efficiency Loan Money lent to customers, usually at a reduced interest rate, for the purchase of energy efficient/renewable energy equipment. Repayment schedules vary.

- Energy Efficiency Mortgage (EEM) A type of energy efficiency loan where the efficiency of a home is taken into account by mortgage brokers assessing an applicant's loan eligibility.

1. This document is FCS3268, one of an Energy Efficient Homes series of the Family, Youth and Community Sciences Department, Florida Cooperative Extension Service, Institute of Food and Agricultural Sciences, University of Florida. This material was prepared with the support of the Department of Environmental Protection, Florida Energy Office. However, any opinions, findings, conclusions, or recommendations expressed herein are those of the author(s) and do not necessarily reflect the views of the Florida Department of Environmental Protection. Original publication date: June 2008. Visit the EDIS Web Site at http://edis.ifas.ufl.edu.

2. Nicholas W. Taylor, research associate; M. Jennison Kipp, resource economist; Kathleen C. Ruppert, associate extension scientist; Program for Resource Efficient Communities; University of Florida, Gainesville, FL 32611

The Institute of Food and Agricultural Sciences (IFAS) is an Equal Opportunity Institution authorized to provide research, educational information and other services only to individuals and institutions that function with non-discrimination with respect to race, creed, color, religion, age, disability, sex, sexual orientation, marital status, national origin, political opinions or affiliations. U.S. Department of Agriculture, Cooperative Extension Service, University of Florida, IFAS, Florida A. \& M. University Cooperative Extension Program, and Boards of County Commissioners Cooperating. Larry Arrington, Dean 
- Giveaway Products or services given by utility providers or product manufacturers to encourage the use of a product or behavior.

- Tax Credit Reduction of income taxes owed to encourage customer investments in a new product or service.

- Tax Deduction Reduction of the amount of income subject to tax liability to encourage customer investments in a new product or service.

- Manufacturer Rebate Money given by the manufacturer of a product to customers after they have made a purchase in order to lower the final cost to the customer and increase sales of a product.

\section{Who offers incentives and why?}

Energy efficiency upgrades often require substantial financial investments. For homeowners, this may mean that even though investments in energy efficiency upgrades make sound financial sense in the long run, they may not be financially feasible in the short run. To address this and other concerns, such as power plant inefficiencies, increased power demand, and environmental and health issues, utility providers, states, and the federal government provide incentives to help homeowners bridge the gap between energy efficiency and project affordability. Incentives are increasingly a large part of most utility providers' demand-side management programs, the intent being to increase their own efficiency in production and extend lower energy prices to their customers. There are many types of incentives available to you, the "end-user," such as rebates, loan programs, and giveaways, and they are often coupled with manufacturer rebates to further reduce the financial burden of investments on customers.

\section{What types of energy efficiency incentives are there?}

Energy efficiency incentives generally fall into one of five categories: structural, mechanical, appliances, lighting, and alternative energy. Table 1 briefly outlines the typical incentives that apply to specific energy efficiency upgrades, but there is one other key incentive to consider first, and that's the energy audit.

\section{Energy audit}

The energy audit is not only one of the most common energy efficiency incentives offered, but also it is arguably the most valuable. Utility providers often have trained energy efficiency consultants on staff to help customers identify particular areas where energy efficiency improvements can be made. Consultants will inspect many different features of the home that are often inefficient, yet which typical customers may inadvertently overlook as opportunities for improving energy efficiency. Before you make any major energy efficiency upgrades, consult a professionally trained energy efficiency expert.

\section{Structural}

Generally, a home's structural features are the first elements to consider when identifying areas for improvements in energy efficiency. Rebates are given to customers most often for adding attic insulation and replacing old or inefficient windows. Making these upgrades helps to lower the demand on a home's heating and air-conditioning systems, allowing for replacement of mechanical systems with smaller, more efficient, and more economical units. These renovations often qualify for loan programs that target residential energy efficiency. Some incentives, such as giveaways of weather-stripping and caulking, target leak reduction and improvements in overall home weatherization. These small changes reduce the exchange of air between the home and the outdoors, making your conditioned space less drafty and reducing your home's heating and air conditioning needs.

\section{Mechanical}

In most Florida homes, mechanical systems are the largest energy users, so they are often strong candidates for incentive programs. A home's mechanical system primarily consists of the heating, ventilation and air conditioning (HVAC) components. The performance of these systems is affected largely by the quality and condition of the home's windows and attic insulation. HVAC 
ductwork, which conveys conditioned air throughout the home, can be a major source of energy loss as any leaks will result in loss of cooled or heated air as well as infiltration of unconditioned air. Many utilities offer rebates for having HVAC systems and ductwork sealed and serviced by licensed professionals. For replacement of central air conditioning systems, federal tax credits and many utility and manufacturer rebates may apply. In addition, most energy efficiency loan programs apply particularly to HVAC upgrades.

\section{Appliances}

In most Florida homes, the second largest energy use is for heating water. Federal tax credits, energy efficient loan programs, and manufacturer rebates have been offered for upgrading to energy efficient water heaters and other appliances, and this trend appears to be continuing. Generally, new appliances must meet a certain ENERGY STAR® level to qualify, so be sure to know the requirements of the incentive program you are pursuing, and the manufacturer information for the appliance you are considering. Finally, ask the sales person to verify that you are purchasing a qualified model. If your home site is a candidate for alternative energy technologies such as solar or wind generated power, appliances like solar water heaters currently offer the quickest return on investment. To date, the "Sunshine State" offers many incentives for solar water heating, which are discussed in the section below on alternative energy incentives.

\section{Lighting}

Upgrading incandescent lighting to more energy efficient, low wattage lighting, such as compact fluorescent lamps (CFLs), is a relatively low cost investment, making it ineligible for many incentive programs. Often, however, you can get CFLs through giveaways, at utility buy-down programs through local vendors, or at other local energy efficiency events. It is especially important to value quality over pricing when purchasing CFLs as this is critical to receiving the proper energy efficiency return on your financial investment.

\section{Alternative Energy}

Currently, some of the largest incentives offered are for alternative energy technologies. The State of Florida has implemented rebate programs to encourage the installation of solar photovoltaic (PV) panels, solar water heaters, and solar pool heaters. Most utility providers follow suit with supplementary rebates for solar PV panels and solar water heaters. Federal tax credits may also apply to solar PV, solar water heating, fuel cells, and other solar-electric technologies.

\section{What should I look for when considering energy efficiency incentive programs?}

When choosing which energy efficiency upgrades to make in your home, it is important to consider carefully which ones will be most helpful in actually reducing your energy use. To get the greatest financial benefit when making upgrades, you must know which incentive programs are available to you, the products and services to which they apply, and the specific details of each program. For the most current information regarding federal, state, and utility provider energy efficiency incentives visit the Database of State Incentives for Renewables \& Efficiency. To get the most accurate and complete information about the incentives available now in your particular area, contact your utility provider and a trusted local vendor who supplies the product or service of interest.

Isn't it time your home started paying you back for a change?

\section{References and Resources}

"Connecting You to Renewable Energy Professionals." Find Solar. Energy Matter LLC. 1 May 2008. http://www.findsolar.com/

"Database of State Incentives for Renewables \& Efficiency." NC Solar Center. NC State University. 24 Apr. 2008. http://www.dsireusa.org/

"Federal Tax Credits for Energy Efficiency." Energy Star. US Environmental Protection Agency, US Department of Energy. 24 Apr. 2008. 
Table 1. Home categories and features targeted by typical energy incentive programs.

\begin{tabular}{|c|c|c|}
\hline Category & Feature & Typical Incentive \\
\hline Structural & $\begin{array}{l}\text { - Attic Insulation } \\
\text { - Windows } \\
\text { - Reflective Roof } \\
\text { - Weatherization } \\
\end{array}$ & $\begin{array}{l}\text { - Utility Rebate Programs } \\
\text { - Federal Tax Credit } \\
\text { - Manufacturer Rebates }\end{array}$ \\
\hline Mechanical & $\begin{array}{l}\text { - Duct Sealing } \\
\text { - HVAC Service } \\
\text { - HVAC Replacement } \\
\end{array}$ & $\begin{array}{l}\text { - Utility Rebate Programs } \\
\text { - Federal Tax Credit } \\
\text { - Manufacturer Rebates }\end{array}$ \\
\hline Appliances & $\begin{array}{l}\text { - Water Heater } \\
\text { - Refrigerator } \\
\text { - Washer } \\
\text { - Dryer }\end{array}$ & $\begin{array}{l}\text { - Federal Tax Credit } \\
\text { - Loan Programs } \\
\text { - Manufacturer Rebates }\end{array}$ \\
\hline Lighting & $\begin{array}{l}\text { - Compact Fluorescent Lamps (CFLs) } \\
\text { - Light Emitting Diodes (LEDs) }\end{array}$ & - Utility and Manufacturer Giveaways \\
\hline $\begin{array}{l}\text { Alternative } \\
\text { Energy }\end{array}$ & $\begin{array}{l}\text { - Solar Water Heating } \\
\text { - Solar Photovoltaic Panels }\end{array}$ & $\begin{array}{l}\text { - Federal Tax Credit } \\
\text { - State Rebate Program } \\
\text { - Utility Rebates } \\
\text { - Loan Programs }\end{array}$ \\
\hline
\end{tabular}

http://www.energystar.gov/

index.cfm?c=products.pr_tax_credits\#s2

"Special Offers and Rebates from Energy Star Partners." Energy Star. US Environmental Protection Agency, US Department of Energy. 24 Apr. 2008. http://www.energystar.gov/

index.cfm?fuseaction=rebate.rebate_locator

"Solar Electricity Rebates and Incentives."

Florida Solar Energy Center. University of Central

Florida. 24 Apr. 2008.

http://www.fsec.ucf.edu/en/consumer/

solar_electricity/rebates.htm 